\title{
Effects of the neem extract (Azadirachta indica) on mammalian reproduction
}

\begin{abstract}
Our goal was to show some of the effects of the neem (Azadirachta indica) extract on mammalian reproduction, based on in vivo experiments. The need derivatives are used mainly in veterinary and organic agriculture for the control of insects and ticks and are also employed in traditional medicine in some Asian countries as antibacterial spermicide substances, and for treating diabetes. Despite their widespread use, the side effects of $A$. indica extracts on mammalian reproduction have been reported.
\end{abstract}

Keywords: azadirachta indica, neem, meliaceae, reproduction, mammalian
Volume 7 Issue 2 - 2018

\author{
Magda Regina Santiago,' Lígia Maria Salvo² \\ 'Centro de Pesquisa e Desenvolvimento de Proteção Ambiental, \\ Brazil \\ ${ }^{2}$ Instituto de Ciências Biomédicas da Universidade de São Paulo \\ (USP), Brazil
}

\author{
Correspondence: Magda Regina Santiago, Toxicology Lab, \\ Centre of Research and Development of Environmental, \\ Instituto Biológico. Av. Conselheiro Rodrigues Alves, I 252 - Vila \\ Mariana, CEP 040 I4-900, São Paulo - SP, Brazil,Tel +55 II \\ 50871757,Email santiago@biologico.sp.gov.br
}

Received: March 01, 2018 | Published: April 13, 2018

Abbreviations: TD50, total degradation period; usually expressed in days that are necessary to degrade the mass to the half; MRL, maximum residue level; which is the maximum amount of a given active ingredient tolerated in food grown under good agricultural practice and respecting the time interval in days between the last application of the pesticide and the harvesting or marketing of this food; ROS, reactive oxygen species

\section{Introduction}

Azadirachta indica, popularly known as neem, is a tree-sized species of the Meliaceae family, native to the Indian subcontinent This tree provides material that is widely used in several areas including agriculture, veterinary medicine, therapeutic medicine, and wood harvesting due to its large size. The azadirachtin (triterpenoid) is its main compound; besides, $A$. indica has other limonoid compounds like nimbolide, nimbin, and salannin.

Neem extracts from leaves and seeds can be industrialized and used as insecticides and fungicides in both traditional and organic agriculture. ${ }^{1}$ The main physicochemical and degradation characteristics of azadirachtin are: relatively low solubility in water, $260 \mathrm{mg} . \mathrm{L}^{-1}$ $\left(20^{\circ} \mathrm{C}-25^{\circ} \mathrm{C}\right)$; insoluble in hexane; dark stability, $\mathrm{TD}_{50}=50$ days $(\mathrm{pH}$ 5 , room temperature); and soil stability, $\mathrm{TD}_{50}=25$ days. In insects, the azadirachtin acts as an antagonist on ecdysone, interrupting the development of larvae. ${ }^{2}$ Besides, the neem seed oil is used in traditional medicine as a spermicide, anti-fertility, antibacterial, and healing substance, and for treating diabetes. ${ }^{3}$

\section{Discussion}

According to the Environmental Protection Agency (EPA), the formulations based on azadirachtin belong to the toxicological class EPA IV. Specifically for Brazil, these formulations were recently reevaluated by the Brazilian Health Regulatory Agency (ANVISA), ${ }^{4}$ which currently states the non-restriction of their MRL in neem-based commercial pesticides. ${ }^{5}$ Although some researchers have concluded that the azadirachtin technical grade did not present mutagenic and teratogenic effects in mammals, other researchers have demonstrated an opposite effect, especially regarding its reproductive effects in mammals. ${ }^{1,6-11}$

Previous work has shown that the oil of $A$. indica administered at $1.2 \mathrm{~mL} /$ day from the first day after fertilization and during the whole pregnancy in a group of female Wistar rats influenced fetal malformation. ${ }^{12}$ On the other hand, the azadirachtin administered at $1.0 \mathrm{mg} /$ day in another group of female Wistar rats in that same study did not negatively affect fetuses within 17 days after fertilization, a result probably related to the presence of linoleic acid in the neem oil. ${ }^{12}$ "Dallaqua et al. ${ }^{12}$ verified that the neem oil presented a higher proportion of fatty acids, especially linoleic acid ... The linoleic acid is a polyunsaturated fatty acid (PUFA) derived from the diet, and dietary intake influences its availability". ${ }^{12}$

However, neem oil related to dietary intake of PUFAs can increase fetal malformation in rats. ${ }^{13}$ Pregnant women have used neem derivatives as an antidiabetic, ${ }^{14,15}$ an antibiotic, ${ }^{16}$ and also to reduce symptoms of Chagas disease. ${ }^{17}$ However, until 2012, studies on the medicinal properties of neem and its side effects were conducted on non-pregnant animals and reached divergent conclusions. ${ }^{18}$ A study on the neem oil performed in 2012 revealed that this substance had no hypoglycemic effects on non-diabetic female rats, and no antihyperglycemic effects in diabetic female rats. ${ }^{18}$ Another study concluded that the neem leaf extract significantly increased the activities of caspase- 9 and caspase- 3 in oocytes collected from animals treated with this extract, which presented apoptotic morphological characteristics. ${ }^{8}$ In this study, the neem leaf extract generated ROS, and the release of cytochrome $\mathrm{c}$ from mitochondria led to morphological changes associated with oocyte apoptosis. ${ }^{8}$

The alcoholic extract of flowers from $A$. indica harmed the ovulation of adult Sprague-Dawley rats, suggesting its viability as a contraceptive; however, because it may affect fertility, the researchers recommended further experiments, specifically with primates and humans. ${ }^{19}$ On the other hand, fetal implantation and development were not affected. ${ }^{19}$

Another study evaluated whether dietary intake of azadirachtin 
technical grade at concentrations $100 \mathrm{ppm}, 500 \mathrm{ppm}$, and 1,000ppm would influence the reproductive performance of rats Rattus norvegicus over two generations..$^{20}$ Female rats, fed with azadirachtin and evaluated by the absence of clinical signs and molecular and histopathological analyses, showed no signs of toxicity or teratogenic effects in the F1 and F2 generations. ${ }^{20}$

The ingestion of extracts of polar and apolar fractions of $A$. indica seeds was tested in female albino rats aiming at the control of rats severely affecting the Indian agricultural production. ${ }^{1}$ After the tests, the researchers found a reduction in the normal follicles production. Besides, leaf powder of $A$. indica and leaf powder of $A$. indica plus testosterone administered in albino rats for 48days damaged the Sertoli cells. ${ }^{9}$ Comparisons of neem-treated rats and testosteronetreated rats, through assessments of ultrastructural changes, indicated that leaf extracts of $A$. indica could affect spermatogenesis. ${ }^{10}$ Another study also performed on male rats showed that animals ingesting an aqueous wood-ash extract obtained from neem barks did not increase their level of testosterone. ${ }^{13}$ However, the rats showed changes in spermatozoon concerning morphology, viability, motility, and total count, which was reduced in direct proportion to the increase in the $A$. indica concentration. ${ }^{13}$ The authors concluded that spermatogenesis was affected in the pre-meiotic stage of gametogenesis and that therefore the neem extract may cause germ cell mutations, before or during the reproductive period, transmitting these mutations to the offspring, and making somatic cells susceptible to carcinogenicity or teratogenicity. ${ }^{13}$

\section{Conclusion}

We must be cautious when stating that apparently innocuous substances like the neem extract do not cause deleterious effects on organisms, including humans. More in-depth studies with neem ought to be conducted. Regarding the environment, the use of neem derivatives in field crops may cause ecological imbalance since it is a non-selective pesticide and thus can reach non-target organisms, including more than 600 species of insects. ${ }^{21}$ Finally, it is important to highlight that indiscriminate use of highly toxic pesticides has led to severe problems around the globe, including insect resistance and environmental contamination.

\section{Acknowledgements}

None.

\section{Conflict of interest}

The author declares no competing interests, including financial.

\section{References}

1. Forim MR. Processo de obtenção de nanopartículas biopoliméricas e micropartículas em pó contendo óleo e extratos de Azadirachta indica A. Juss (neem). Legal requeriment of patent. 2014.

2. Turner JA. Azadirachtin. 17th ed. In: The Pesticide Manual. British Crop Production Council, United Kingdom: Hampshire; 2015: 57-58.

3. Roop JK, Dhaliwal PK, Guraya SS. Extracts of Azadirachta indica and Melia azedarach seeds inhibit folliculogenesis in albino rats. Braz J Med Biol Res. 2005;38(6):943-947.

4. U.S. Environmental Protection Agency (USEPA). Special Report on Environmental Endocrine Disruption: An Effects Assessment and Analysis. Washington; 1997.
5. http://portal.anvisa.gov.br/documents/10181/3230998/ CONSULTA+PUBLICA+N+294+GGTOX.pdf/56324bda-d9df-4690a71c-8b42f6b58b6c

6. Raizada RB, Srivastava MK, Kaushal RA, et al. Azadirachtin, a neem biopesticide: subchronic toxicity assessment in rats. Food Chem Toxicol. 2001;39(5):477-483.

7. Srivastava MK, Raizada RB. Assessment of embryo/fetotoxicity and teratogenicity of azadirachtin in rats. Food Chem Toxicol. 2001;39(10):1023-1027.

8. Tripathi A, Tulsidas G Shrivastav, Shail K Chaube. Aqueous extract of Azadirachta indica (neem) leaf induces generation of reactive oxygen species and mitochondria-mediated apoptosis in rat oocytes. J Assist Reprod Genet. 2012;29(1):15-23.

9. Aladakatti RH, Ahamed RN. Changes in Sertoli cells of albino rats induced by Azadirachta indica A. Juss leaves. J Basic Clin Physiol Pharmacol. 2005;16(1):67-80.

10. Kasturi M, Ahamed RN, Pathan KM, et al. Ultrastructural changes induced by leaves of Azadirachta indica (Neem) in the testis of albino rats. $J$ Basic Clin Physiol Pharmacol. 2002;13(4):311-328.

11. Auta T, Hassan AT. Reproductive toxicity of aqueous wood-ash extract of Azadirachta indica (neem) on male albino mice. Asian Pacific Journal of Reproduction. 2016;5(2):111-115.

12. Dallaqua B, Saito FH, Rodrigues T, et al. Azadirachta Indica treatment on the congenital malformations of fetuses from rats. J Ethnopharmacol. 2013;150(3):1109-1113.

13. Weiss LA, Chambers CD, Gonzalez V, et al. The omega- 6 fatty acid linoleic acid is associated with risk of gastroschisis: a novel dietary risk factor. Am J Med Genet. 2012;158A(4):803-807.

14. Waheed A, Miana GA, Ahmad SI. Clinical investigation of hypoglycemic effect of seeds of Azadirachta indica in type-2 (NIDDM) diabetes mellitus. PakJ Pharm Sci. 2006;19(4):322-325.

15. Bhat M, Zinjarde SS, Bhargava SY, et al. Antidiabetic Indian plants: a good source of potent amylase inhibitors. Evid Based Complement Alternat Med. 2011:810207.

16. Sharma A, Chandraker S, Patel VK, et al. Antibacterial activity of medicinal plants against pathogens causing complicated urinary tract infections. Indian J Pharm Sci. 2009;71(2):136-139.

17. Mbaya AW, Ibrahim UI, God OT, et al. Toxicity and potential antitrypanosomal activity of ethanolic extract of Azadirachta indica (Meliacea) stem bark: an in vivo and in vitro approach using Trypanosoma brucei. J Ethnopharmacol. 2010;128(2):495-500.

18. Dallaqua B, Saito FH, Rodrigues T, et al. Treatment with Azadirachta indica in diabetic pregnant rats: negative effects on maternal outcome. $J$ Ethnopharmacol. 2012;143(3):805-811.

19. Gbotolorun SC. Osinubi AA, Noronha CC, et al. Antifertility potential of Neem flower extract on adult female Sprague-Dawley rats. Afr Health Sci. 2008;8(3):168-117.

20. Srivastava MK, Raizada RB. Lack of toxic effect of technical azadirachtin during postnatal development of rats. Food Chem Toxicol. 2007;45(3):465471.

21. Moacir Rossi Forim, Andréia Pereira Matos, Maria Fátima das Graças Fernandes da Silva, et al. Uso de CLAE no controle de qualidade em produtos comerciais de nim: reprodutibilidade da ação inseticida. Quimica Nova. 2010;33(5):1082-1087. 